\title{
A VIDA NAS ORGANIZAÇÕES PRESTADORAS DE SERVIÇOS
}

\author{
Isabel Amélia Costa Mendes ${ }^{1}$
}

\begin{abstract}
"A história da condição humana ilustra a
busca da humanidade para se libertar do trabalho que não seja digno de um viver verdadeiramente humano"(1).
\end{abstract}

\begin{abstract}
Há um consenso generalizado de que as organizações da atualidade devem se submeter a uma mudança fundamental.

Mais do que nunca, na história do contexto de trabalho, as pessoas hoje sofrem ansiedade, estresse, sentem-
\end{abstract} se freqüentemente em estado de alerta, às vezes confusas ou excessivamente concentradas, sempre esperando o inesperado, desconsideram o outro, são incapazes de se divertir e em seus semblantes podemos observar indiferença frente a qualquer evento que não seja dirigido a sua labuta do dia-a-dia. O descontentamento e a infelicidade estão sempre presentes. Em suas vidas, apesar de tanta busca e de tanto encontro, parece que permanece o vazio. Mas, as pessoas continuam buscando...

Esses sintomas são respostas aos sistemas organizativos em que se encontram. São uma reação aos comportamentos mecânicos de si próprias, de seus pares e de seus dirigentes. Em todos há o sentimento de serem manipulados como se fossem engrenagens de máquinas,pois concebem 'sua' organização como uma máquina que privilegia a eficiência e usa em larga escala o controle.

A mudança fundamental que mencionamos refere-se à compreensão da organização como sistema vivo. "...A vida de uma organização - sua flexibilidade, seu potencial criativo, sua capacidade de aprendizado - reside em suas comunidades informais de prática"(2).

Para o fortalecimento de comunidades nas organizações, “.... primeiro passo nessa direção está em proporcionar o espaço social necessário para que floresçam as comunicações informais”"(2). Dentre as vantagens dessas comunicações, a autenticidade e a liberdade fortalecerão a vida pessoal, e a aquisição de conhecimento tácito certamente se refletirá em suas ações profissionais.

Em sua busca constante as pessoas querem encontrar um significado para a vida e na vida está integrado o trabalho. Encontrar significado para realizar o trabalho, principalmente em organizações prestadoras de serviços, ou seja, encontrar significado em prestar serviço cuidando do outro, utilizando seu potencial biológico, mental e espiritual e, nesta perspectiva, conhecendo-se, compreendendo-se e doando-se, antes de tudo a si mesma, a pessoa será capaz, mostrará competência e contentamento em cuidar do outro.

Os valores do espírito implementados na prática energizam as relações humanas e, assim, pode-se esperar a melhoria da qualidade de vida.

\section{REFERÊNCIAS BIBLIOGRÁFICAS}

1. Mendes IAC. Ação do enfermeiro frente às novas demandas do homem. Rev Latino-am Enfermagem 2001 julho; 9(4):1.

2. Capra F. As conexões ocultas. Ciência para uma vida sustentável. São Paulo (SP): Cultrix; 2002.

\footnotetext{
${ }^{1}$ Editor da Revista Latino-Americana de Enfermagem, Diretor, Professor Titular da Escola de Enfermagem de Ribeirão Preto, da Universidade de São Paulo, Centro Colaborador da OMS para o desenvolvimento da pesquisa em enfermagem, e-mail: iamendes@eerp.usp.br
} 


\title{
LIFE IN SERVICE ORGANIZATIONS
}

\begin{abstract}
"The history of the human condition illustrates humanity's search to be freed from work that is not worthy of a truly humane life"(1).
\end{abstract}

Everybody agrees about the fact that, nowadays, organizations have to submit to a radical change.

These days more than ever, in the history of the labor context, people suffer from anxiety and stress, a frequent state of increased alertness, sometimes confused or excessively concentrated, always expecting the unexpected, they have no more consideration for other human beings, incapable of having fun and indifferent to anything unrelated to their daily work routine. Dissatisfaction and unhappiness are always present. In spite of so many searches and meetings, there seems to be a permanent void. But people keep on looking...

The symptoms occur in response to the organizational systems they are inserted in. They are a reaction to their own mechanical behavior, that of their peers and managers. All of them feel as if they are being manipulated like machine parts, since they conceive 'their' organization as a machine that privileges efficiency and uses control on a large scale.

The fundamental change we mentioned refers to the understanding of the organization as a living system. "...The life of an organization - its flexibility, its creative potential, its learning capacity - lies in its informal practice communities"(2).

In order to strengthen communities within organizations, "...the first step in this direction is to offer the necessary social space for informal communities to flourish"(2). Advantages of these communities include authenticity and freedom, which will strengthen personal life, and the acquisition of tacit knowledge will certainly reflect on their professional actions.

In their constant search, people want to find a meaning for life, and work is integrated in it. It is in finding a meaning for carrying out work, mainly in service organization, that is, in finding a meaning for rendering service by caring for others, using their biological, mental and spiritual perspective and, in this perspective, in obtaining self-knowledge, self-understanding and giving, to themselves in the first place, that people will be able to demonstrate competency and satisfaction about caring for others.

The spiritual values that are implemented in practice energize human relations and, thus, a better quality of life can be expected.

\section{REFERENCES}

1. Mendes IAC. Ação do enfermeiro frente às novas demandas do homem. Rev Latino-am Enfermagem 2001 julho; 9(4):1.

2. Capra F. As conexões ocultas. Ciência para uma vida sustentável. São Paulo (SP): Cultrix; 2002.

\footnotetext{
${ }^{1}$ Editor of Latin American Journal of Nursing, Dean, Full Professor of the University of São Paulo at Ribeirão Preto College of Nursing - WHO Collaborating Centre for Nursing Research Development, e-mail: iamendes@eerp.usp.br
} 


\title{
LA VIDA EN LAS ORGANIZACIONES PRESTADORAS DE SERVICIO
}

Isabel Amélia Costa Mendes ${ }^{1}$

\author{
"La historia de la condición humana ilustra la \\ búsqueda de la humanidad para liberarse del trabajo que no sea \\ digno de una vida verdaderamente humana"(1)
}

Hay un consenso generalizado en torno a los cambios fundamentales a los que se deben someter las organizaciones en la actualidad.

Más que nunca, en la historia del contexto del trabajo, las personas hoy sufren ansiedad, estrés, se sienten frecuentemente en estado de alerta, a veces confusas o excesivamente concentradas, siempre esperando lo inesperado, no consideran al otro, son incapaces de divertirse y en sus semblantes se puede observar la indiferencia frente a cualquier evento que no sea dirigido a sus labores del día a día. El descontento y la infelicidad están siempre presentes. En sus vidas, a pesar de tanta búsqueda y de tanto encuentro, parece que permanece el vació. Pero, las personas continúan buscando...

Estos síntomas son respuestas a los sistemas organizativos en que se encuentran. Son una reacción a los comportamientos mecánicos de si mismas, de sus pares y de sus dirigentes. En todos hay una sensación de sentirse manipulados, como si fuesen engranajes de maquinas, pues conciben "su" organización como una maquina que privilegia la eficiencia y usa a gran escala el control.

El cambio fundamental que mencionamos se refiere a la comprensión de la organización como sistema vivo “....La vida de una organización, - su flexibilidad, su potencial creativo, su capacidad de aprendizaje - reside en sus comunidades informales de practica"(2).

Para el fortalecimiento de comunidades en las organizaciones, “... el primer paso en esa dirección está en proporcionar el espacio social necesario para que florezcan las comunicaciones informales"(2). Dentro de las ventajas de esas comunicaciones, la autenticidad y la libertad fortalecerán la vida personal y la adquisición de conocimiento tácito, ciertamente se reflejará en sus acciones profesionales.

En su búsqueda constante, las personas quieren encontrar un significado para la vida y en la vida esta integrado el trabajo. Encontrar significado para realizar el trabajo, principalmente en organizaciones prestadoras de servicios, es decir, encontrar significado en prestar servicio cuidando del otro, utilizando su potencial biológico, mental y espiritual y en esta perspectiva, conociéndose, comprendiéndose y donándose, antes que todo a sí misma, la persona será capaz, mostrará competencia y alegría para cuidar al otro.

Los valores del espíritu implementados en la práctica fortalecen las relaciones humanas, le dan energía a las mismas, pudiéndose así esperar mejoras en la calidad de vida.

\section{REFERENCIAS BIBLIOGRÁFICAS}

1. Mendes IAC. Ação do enfermeiro frente às novas demandas do homem. Rev Latino-am Enfermagem 2001 julho; 9(4):1.

2. Capra F. As conexões ocultas. Ciência para uma vida sustentável. São Paulo (SP): Cultrix; 2002.

\footnotetext{
${ }^{1}$ Editor de la Revista Latinoamericana de Enfermería, Director, Profesor Titular de la Escuela de Enfermería de Ribeirão Preto, de la Universidad de São Paulo, Centro Colaborador de la OMS para el desarrollo de la investigación en enfermería, correo electrónico: iamendes@eerp.usp.br
} 
